\title{
New Approach to Modeling a Solar Cell in Relation to Its Efficiency-Laplace Transform Technique
}

\author{
Mohamed Abdelhady Kamel El-Adawi' ${ }^{1}$, Ibtissam Abdelrahman Al-Nuaim² \\ ${ }^{1}$ Physics Department, Faculty of Education, Ain Shams University Heliopolis, Cairo, Egypt \\ ${ }^{2}$ Physics Department, Faculty of Science for Girls, Dammam University, Saudi Arabia \\ Email: adawish1@hotmail.com
}

Received 13 May 2014; revised 12 June 2014; accepted 11 July 2014

Copyright (C) 2014 by authors and Scientific Research Publishing Inc.

This work is licensed under the Creative Commons Attribution International License (CC BY). http://creativecommons.org/licenses/by/4.0/

(c) (i) Open Access

\begin{abstract}
Heating a solar cell subjected to incident solar irradiance is studied. Laplace Integral Transform technique is applied to get the temperature field within the cell. The efficiency as a function of the cell temperature is estimated, and its variation with the local day time is thus clarified. Different cooling levels are considered. An illustrative example is given. The results show that the diurnal temperature variation of the cell is significant, while the efficiency is revealed to be a slowly varying function of temperature along the day time. It is revealed that as the temperature of the cell increases the efficiency decreases. Thus shading and cooling conditions may be useful to increase its efficiency.
\end{abstract}

\section{Keywords}

Solar Cell, Efficiency, Temperature Field within a Solar Cell, Laplace Transform Technique

\section{Introduction}

Manufacturing of photovoltaic energy convertors with higher efficiencies is an important challenge. This topic has aroused the interest of many investigators [1]-[23].

Heating a solar cell subjected to the incident global solar radiation affects its photovoltaic performance [17][23]. The solar $p-n$ cell is a semiconductor photovoltaic device. The main parameters that characterize the solar cell outputs are [24]: the short circuit current $I_{s c}(T)$, the open-circuit voltage $V_{o c}(T)$, and the diode saturation current $I_{0}(T)$.

Such parameters depend principally on the cell temperature [24]. 
The objective of the present trial is to find analytically the temperature of a solar cell subjected to incident global solar radiation and to reveal the variation of its efficiency along the local day time.

Indeed few theoretical trials [15] [16] are made to predict theoretically the cell temperature. These attempts are basically numerically oriented.

In the present work, we aim to find an analytical expression for cell temperature and its variation with the local day time by applying the integral Laplace transform technique as a well established method to solve the heating problem considering the cell as composed of two layers system, as a thin active film in perfect thermal contact with a bulk substrate. This problem is not easy to be solved due to the presence of a boundary condition of fourth kind at the interface between the two layers.

Then we have to correlate this function with the solar cell efficiency through the cell temperature-dependent parameters to reveal its efficiency variation along the solar day length.

\section{Derivation of the Basic Equations}

To set up the heating problems in a general form, it is assumed that the target solar cell consists of two layers (Figure 1).

The front layer (the film layer) is of finite thickness " $d$ ", deposited on a substrate layer of semi-infinite dimensions as shown. The temperature field within the film layer is $\theta_{f}(x, t)$ and that in the substrate layer in $\theta_{\rho}(z, t)$. The solar insulation $q_{0}(t), \mathrm{W} / \mathrm{m}^{2}$ is assumed to fall in $x$-direction perpendicular to the front surface. It is partly absorbed and partly reflected. The absorbed part is $A_{f} q_{0}(t)$.

Where, $A_{f}$ is the absorption coefficient at the surface of the front layer subjected to the incident solar radiation.

Two coincident coordinate axes, $x$ and $z$ are considered. The substrate layer starts at $x=d$, or $z=0$. To find $\theta_{f}$ and $\theta_{\rho}$ the heat diffusion equations for both layers are written as follows:

1) For the front layer:

$$
\frac{\partial \theta_{f}(x, t)}{\partial t}=\alpha_{f} \quad \frac{\partial^{2} \theta_{f}(x, t)}{\partial x^{2}}, t>0, \quad 0 \leq x \leq d
$$

2) In the substrate:

$$
\frac{\partial \theta_{\rho}(z, t)}{\partial t}=\alpha_{\rho} \quad \frac{\partial^{2} \theta_{\rho}(z, t)}{\partial z^{2}}, t>0, \quad 0 \leq z \leq \infty
$$

where, $\alpha=\frac{\lambda}{\rho c_{p}}$ is the thermal diffusivity written in terms of the thermal conductivity $\lambda(=\mathrm{W} / \mathrm{mK})$ and the heat capacity per unit volume $\rho c_{p}, \rho$ is the density $\left(\mathrm{kg} / \mathrm{m}^{3}\right)$ and $C_{p}$ is the specific heat $(\mathrm{J} / \mathrm{kg} \cdot \mathrm{K})$.

$\theta$, represents the excess temperature $\left(T-T_{0}\right)$ relative to the ambient temperature $T_{0}$. The system of Equations (1), and (2) is subjected to the following initial and boundary conditions:

$$
\begin{aligned}
& \theta_{f}(x, 0)=0 \\
& \theta_{\rho}(z, 0)=0
\end{aligned}
$$

At $x=0$,

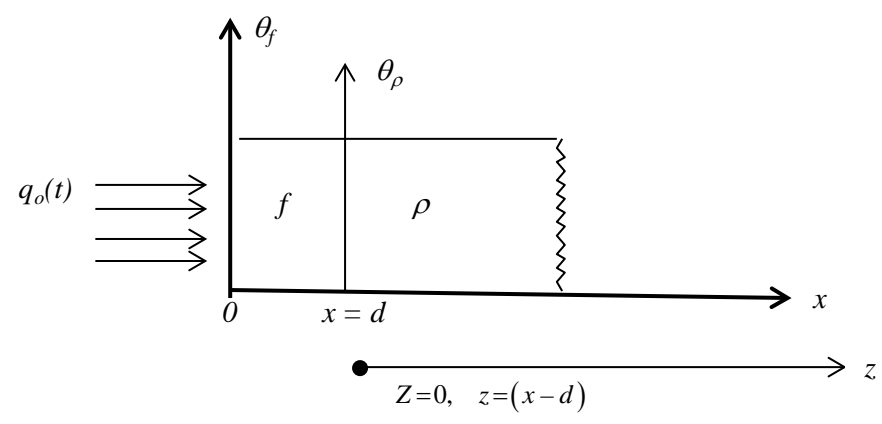

Figure 1. A schematic diagram for the suggested system. 
5)

$$
-\left.\lambda_{f} \frac{\partial \theta_{f}(x, t)}{\partial x}\right|_{x=0}=\xi A_{f} \underset{o}{q}(0, t)-\underset{o}{h} \theta_{f}(0, t)
$$

At the interface between both layers, the boundary condition of the forth kind is:

6)

$$
\begin{gathered}
\theta_{f}(d, t)=\theta_{\rho}(0, t) \\
-\left.\lambda_{f} \frac{\partial \theta_{f}}{\partial x}\right|_{x=0}=-\left.\lambda_{f} \frac{\partial \theta_{\rho}}{\partial z}\right|_{z=0}
\end{gathered}
$$

Moreover, the following condition is accepted:

$$
\theta_{p}(\infty, t)=0
$$

In addition, one has to consider the heat balance condition written in the form:

$$
\int_{0}^{t} \xi A_{f} \underset{o}{q}(t) \mathrm{d} t=\int_{0}^{d} \rho_{f} c_{p_{f}} \theta_{f}(x, t) \mathrm{d} x+\int_{0}^{\infty} \rho_{p} C_{p_{p}} \theta_{p}(z, t) \mathrm{d} z+\int_{0}^{t} h_{0} \theta_{f}(0, t) \mathrm{d} t
$$

$h_{0}\left(\mathrm{~W} / \mathrm{m}^{2} \mathrm{~K}\right)$ is the heat transfer coefficient at the front surface.

And $0<x<1$ is the fraction of the solar energy absorbed at the front surface that is consumed in heating the cell and is not converted into photovoltaic power.

To solve the system of Equations (1), and (2), one has to apply the integral Laplace transform rules to the system and also to the initial and boundary conditions.

Reference [25] solved a laser heating problem similar to the problem considered in the present work. The fundamental difference between both works is that the laser irradiance is considered constant. Moreover cooling conditions are neglected in [25]. These factors are taken into consideration for the present problem.

The incident solar irradiance function $q_{0}(t)$ received on a horizontal surface is taken in the form published elsewhere by the authors of the present work [26].

$$
\underset{o}{q}(t)=4 q_{\max } \frac{t}{t d}\left(1-\frac{t}{t d}\right) \sin \frac{\pi t}{t d}, \mathrm{~W} / \mathrm{m}^{2}
$$

where $q_{\max }$ is the maximum value occurring at a local midday time $t_{\max }$.

$t$ is the local day time starting from sunrise $t_{r}$ up to sunset $t_{s}$.

$t_{d}=\left(t_{s}-t_{r}\right)$ is the length of the solar day given as [27].

$$
t_{d}=\frac{12}{15} \operatorname{Cos}^{-1}(-\tan \varphi \tan \delta) \text {, where } \varphi \text { is the latitude, and } \delta=23.45 \sin 360\left(\frac{284+n^{\prime}}{365}\right)
$$

is the solar declination [27].

$n^{\prime}$ is the day of the year $(1<n<365)$ starting from 1 January. Taking Laplace transform with respect to time and following the same steps as in [25], one can get finally the temperature fields in the form:

In the front layer:

$$
\begin{aligned}
& \therefore \theta_{f}(X, t)=L^{-1}\left\{f_{1}(s) f_{2}(s)\right\} \\
& =\sum_{n=0}^{\infty} \Omega^{n+1} \int_{0}^{t} \frac{4 \xi A_{f} q_{\max }}{\lambda_{f}}\left(\frac{t-u}{t_{d}}\right)\left(1-\left(\frac{t-u}{t_{d}}\right)\right) \sin \left(\pi \frac{(t-u)}{t_{d}}\right)\left[\sqrt{\frac{\alpha_{f}}{\pi u}} \exp \left(\frac{-(2(n+1) d-X)^{2}}{4 \alpha_{f} u}\right)\right.
\end{aligned}
$$

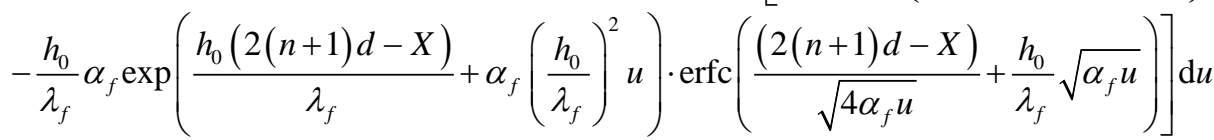

$$
\begin{aligned}
& +\sum_{n=0}^{\infty} \Omega^{n} \int_{0}^{t} \frac{4 \xi A_{f} q_{\max }}{\lambda_{f}}\left(\frac{t-u}{t_{d}}\right)\left(1-\left(\frac{t-u}{t_{d}}\right)\right) \sin \left(\pi \frac{(t-u)}{t_{d}}\right)\left[\sqrt{\frac{\alpha_{f}}{\pi u}} \exp \left(\frac{-(2 n d+X)^{2}}{4 \alpha_{f} u}\right)\right. \\
& \left.-\frac{h_{0}}{\lambda_{f}} \alpha_{f} \exp \left(\frac{h_{0}(2 n d+X)}{\lambda_{f}}+\alpha_{f}\left(\frac{h_{0}}{\lambda_{f}}\right)^{2} u\right) \cdot \operatorname{erfc}\left(\frac{(2 n d+X)}{\sqrt{4 \alpha_{f} u}}+\frac{h_{0}}{\lambda_{f}} \sqrt{\alpha_{f} u}\right)\right] \mathrm{d} u
\end{aligned}
$$


In the substrate:

$$
\begin{aligned}
& \theta_{p}(z, t)=L^{-1}\left\{f_{1}(s) f_{2}(s)\right\} \\
& =\sum_{n=0}^{\infty} \Omega^{n} \int_{0}^{t} \frac{8 A_{f} \xi q_{\max }}{(1+\delta) \lambda_{f}}\left(\frac{t-u}{t_{d}}\right)\left(1-\left(\frac{t-u}{t_{d}}\right)\right) \sin \left(\pi \frac{(t-u)}{t_{d}}\right)\left[\sqrt{\frac{\alpha_{f}}{\pi u}} \exp \left(\frac{-\left(2(n+1) d+\sqrt{\frac{\alpha_{f}}{\alpha_{p}}} z\right)^{2}}{4 \alpha_{f} u}\right)\right. \\
& \left.-\frac{h_{0}}{\lambda_{f}} \alpha_{f} \exp \left(\frac{h_{0}\left(2(n+1) d+\sqrt{\frac{\alpha_{f}}{\alpha_{p}}} z\right)}{\lambda_{f}}+\alpha_{f}\left(\frac{h_{0}}{\lambda_{f}}\right)^{2} u\right) \cdot \operatorname{erfc}\left(\frac{\left(2(n+1) d+\sqrt{\frac{\alpha_{f}}{\alpha_{p}}} z\right)}{\sqrt{4 \alpha_{f} u}}+\frac{h_{0}}{\lambda_{f}} \sqrt{\alpha_{f} u}\right)\right] \mathrm{d} u .
\end{aligned}
$$

where,

$$
\Omega=\frac{1-\delta}{1+\delta}, \quad \delta=\frac{\sqrt{\lambda_{p} \rho_{p} C_{p_{p}}}}{\sqrt{\lambda_{f} \rho_{f} C_{p f}}}
$$

In the present work, data for $q(t)$ published in Jeddah [28], is considered.

where $q_{\max }=910 \mathrm{~W} / \mathrm{m}^{2}$, and $t_{d}=13.18$ hours.

For a single layer system, one has to substitute $\delta=0$ and $\Omega=1$.

The following relations are also considered:

$$
\frac{1}{1-a}=\sum_{n=0}^{\infty} a^{n} \quad|a|<1
$$

2) The convolution theory [29]:

$$
L^{-1}\left\{f_{1}(s) f_{2}(s)\right\}=\int_{0}^{t} f_{1}(t-u) f_{2}(u) \mathrm{d} u
$$

where $f_{1}(s)$ is the Laplace transform of the function $f_{1}(t)$.

And $f_{2}(s)$ is the Laplace transform of the function $f_{2}(t)$.

3) The following inverse Laplace transforms [30] is considered:

$$
L^{-1}\left\{\frac{\exp \left(-\sqrt{\frac{s}{\phi}} x\right)}{\left(\sqrt{\frac{s}{\phi}}+\hbar\right)}\right\}=\sqrt{\frac{\phi}{\pi t}} \exp \left(-\frac{x^{2}}{4 \phi t}\right)-\hbar \phi \cdot \exp \left(\hbar x+\phi \hbar^{2} t\right) \operatorname{erfc}\left(\frac{x}{\sqrt{4 \phi t}}+\hbar \sqrt{\phi t}\right) \text { for } x>0, \phi>0
$$

where, erfc $\equiv$ is the complementary error function.

In the following the variation of the cell efficiency as a function of its temperature is studied where:

The efficiency $\eta$ is defined as [23]:

$$
\eta=\frac{V_{o c} I_{s c} F F}{P_{\text {in }}}
$$

The physical quantities that are function of the temperature are indicated as:

$V_{\text {oc }}$ is the open-circuit voltage with an ideal value [23]:

$$
V_{o c}=\frac{k T}{e} \ln \left(\frac{I_{s c}}{I_{0}}+1\right)
$$

$k$-Boltzmann's constant $\left(=1.38 \times 10^{-23} \mathrm{~J} / \mathrm{k}\right)$.

$e$-is the electron charge $\left(=-1.6 \times 10^{-19}\right.$ coulomb). 
$I_{s c}$-is the short-circuit current, ideally this is equal to the light-generated current.

$I_{s c}$ is given as [31].

$$
I_{s c}=Q A(T)\left(1-\exp (-\alpha \ell) e n_{p h}\left(E_{g}\right),\left(A / \mathrm{m}^{2}\right)\right)
$$

$Q$-is the collection efficiency (is taken as 0.8 ), $A(T)$ is the absorption coefficient for solid silicon at its surface and is given for the range $T=300^{\circ} \mathrm{K}-1685^{\circ} \mathrm{K}$ by the relation [31]:

$$
T=A_{0}+A_{1} T(0, t)=\left(0.678-3.12 \times 10^{-5} \mathrm{~T}\right)
$$

For an ionized donor impurity concentration of value $N_{d}=10^{25} \mathrm{~m}^{-3}$, the temperature variation of the attenuation coefficient $\alpha$ is given by the relation [31]:

$$
\alpha(T)=a \exp \left(T / T_{1}\right)
$$

where, $a=3.17 \times 10^{4} \mathrm{~m}^{-1}$ and $T_{1}=346^{\circ} \mathrm{K}$.

$l, m$ is the thickness of the absorbing semiconductor bulk.

$n_{p h},\left(E_{g}\right)$, is the number of photons with energy greater than the band gap $E_{g}$.

Moreover, $I_{0}$, the diode saturation current is given as in [23] [32].

$$
I_{0}=n T^{3} \exp \left(-\frac{E_{g}}{k T}\right) \quad A m / \mathrm{m}^{2},
$$

where, $n$ is the non-ideality factor, this factor is taken as unity.

Besides, one has to consider the dependence of the band gap on the temperature expressed as in [32]:

$$
E_{g}(T)=E_{g}(0)-\frac{a^{\prime} T^{2}}{T+b}
$$

The values of $E_{g}(0), a^{\prime}$ and $b$ for silicon [32] are:

$E_{g}(0)=1.16 \mathrm{eV}, \quad a^{\prime}=7 \times 10^{-4} \mathrm{eVK}^{-1}, b=1100^{\circ} \mathrm{K}$.

$P_{\text {in }}$ is the received incident solar irradiance $\mathrm{W} / \mathrm{m}^{2}$.

\section{Computations}

As an illustrative example, a single layer $(\Omega=1)$ solar silicon cell of thickness $0.02 \mathrm{~m}$ is considered. Its temperature is computed, at different values of the local day time, $t$, the temperature at $x=0$ for simplicity is accepted as the cell temperature, rather than taken an average value along its thickness.

Corresponding to each value $\theta(t)$ of the cell, one has to compute all the physical quantities required to estimate its efficiency $\eta(t)$ namely, $E_{g}, I_{0}, I_{s c}, V_{o c}$. These functions are given in Table 1 the efficiency $\eta(t)$ as a function of the local day time is illustrated as graphically in Figure 2.

\begin{tabular}{cc|}
\hline Table 1. The efficiency $\eta$ as a function of local day time. \\
\hline Day Time (hours) & $\eta$ \\
\hline 0 & \#DIV/0! \\
2.59 & 0.2846 \\
3.59 & 0.2875 \\
4.59 & 0.2850 \\
5.59 & 0.2805 \\
6.59 & 0.2753 \\
7.59 & 0.2697 \\
8.59 & 0.2642 \\
9.59 & 0.2590 \\
10.59 & 0.2540 \\
11.59 & 0.2473 \\
12.59 & 0.2381 \\
13.18 & 0.2152 \\
\hline
\end{tabular}


The cell temperature as a function of the local day time for three different values of the heat transfer coefficients $h_{0}=3.5,5,10 \mathrm{~W} / \mathrm{m}^{2} \mathrm{~K}$, limiting the cooling conditions, are given in Table 2, Table 3, and Table 4.

The effect of the different cooling levels on $\theta(t)$ is shown graphically in Figure 3.

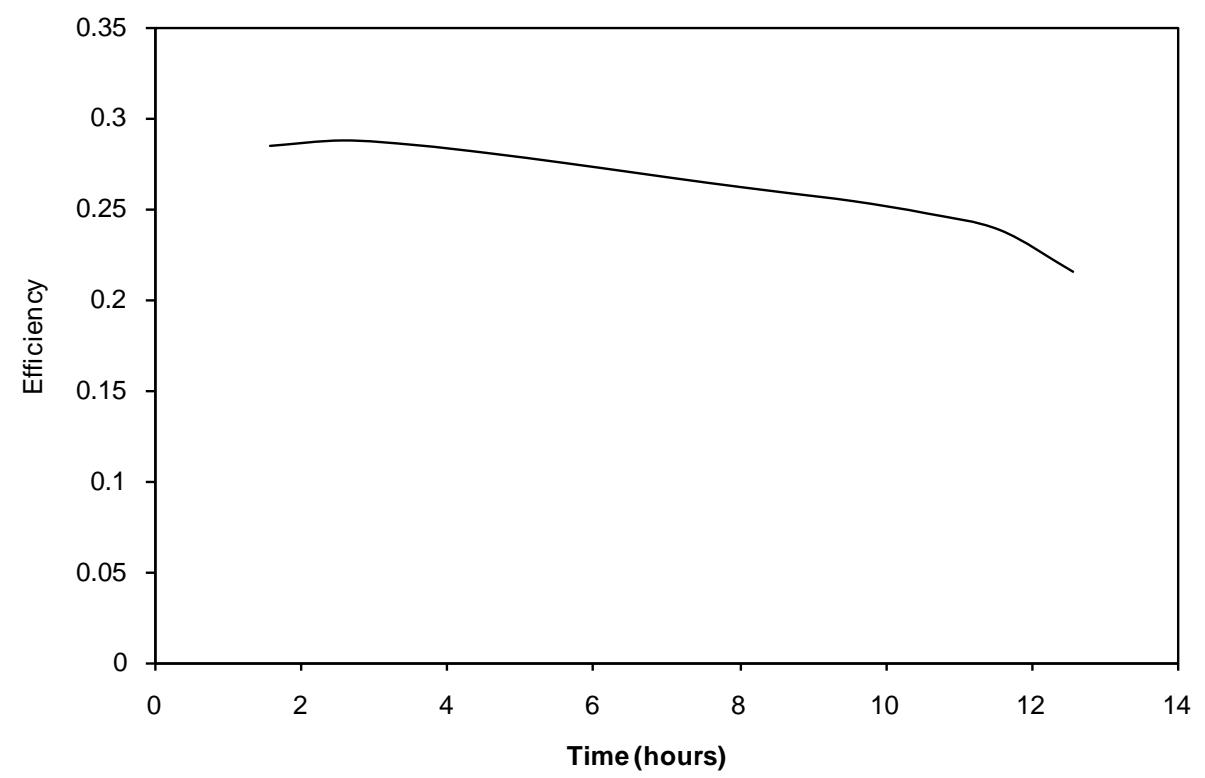

Figure 2. Efficiency as a function of local day time.

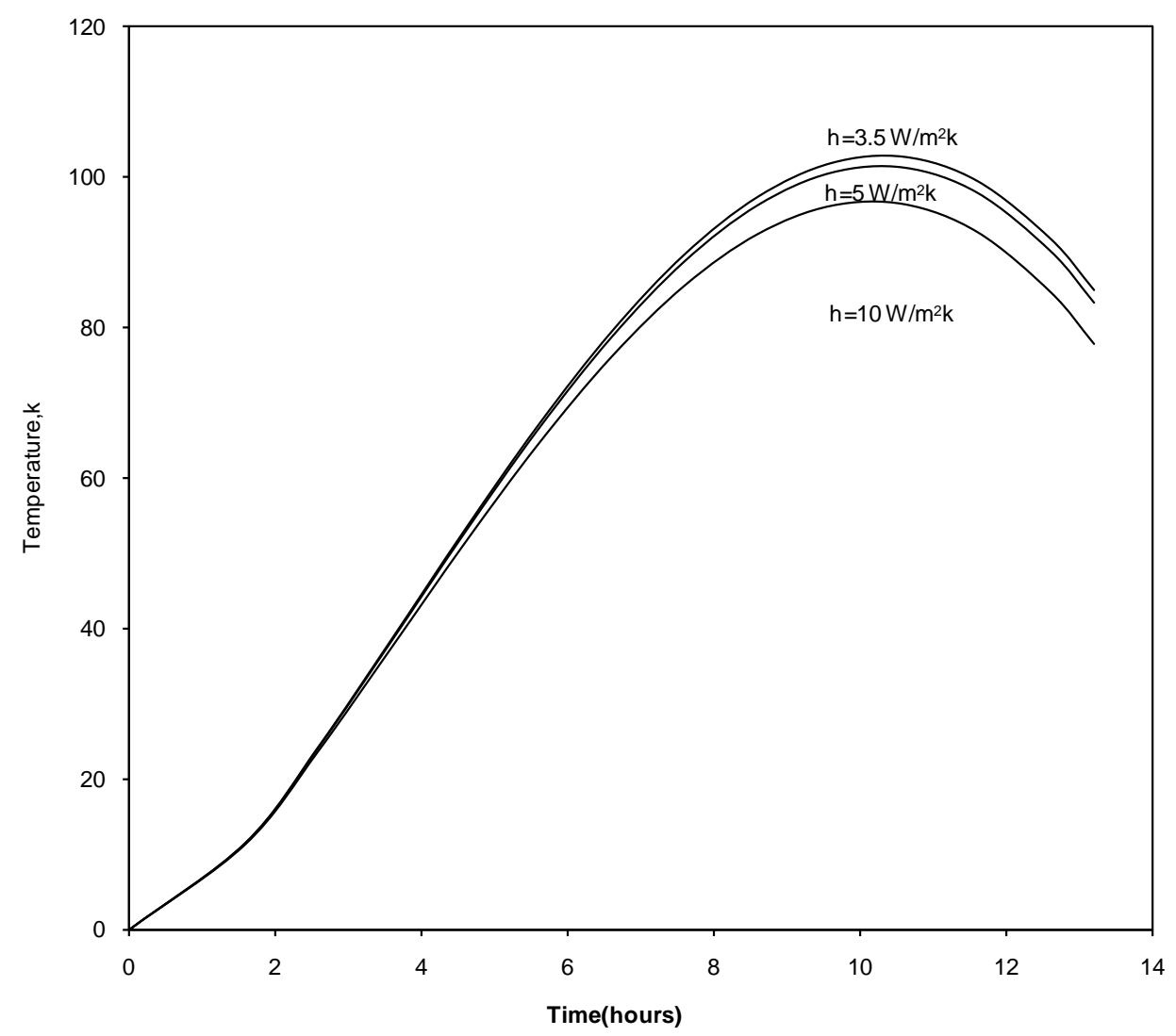

Figure 3. The cell difference temperature as a function of local day time with the coefficient of heat transfer $(\mathrm{h})$, and the thickness $(=0.02 \mathrm{~m})$ as parameters. 
Table 2. The cell difference temperature as a function of local day time, $h_{0}=3.5 \mathrm{~W} / \mathrm{m}^{2} \mathrm{~K}, \quad q_{\max }=910 \mathrm{~W} / \mathrm{m}^{2}, \quad t_{d}=13.18$ hours [11].

\begin{tabular}{cc}
\hline $\begin{array}{c}\text { Time } \\
\text { (hours) }\end{array}$ & $\begin{array}{c}\boldsymbol{\theta} \\
\mathbf{K}\end{array}$ \\
\hline 0 & 0 \\
1.59 & 11.5840 \\
2.59 & 24.4020 \\
3.59 & 38.7130 \\
4.59 & 53.2690 \\
5.59 & 67.1340 \\
6.59 & 79.5470 \\
7.59 & 89.8600 \\
8.59 & 97.5050 \\
9.59 & 101.9700 \\
10.59 & 102.8000 \\
11.59 & 99.5690 \\
12.59 & 91.8720 \\
13.18 & 85.0880 \\
\hline
\end{tabular}

Table 3. The cell difference temperature as a function of local day time with the coefficient of heat transfer $\left(\mathrm{h}_{0}=5 \mathrm{~W} / \mathrm{m}^{2} \mathrm{~K}\right)$ and the thickness $d=0.02 \mathrm{~m}$, taken as parameters.

\begin{tabular}{cc}
$\begin{array}{c}\text { Time } \\
\text { (hours) }\end{array}$ & $\begin{array}{c}\boldsymbol{\theta} \\
\mathbf{K}\end{array}$ \\
\hline 0 & 0 \\
1.59 & 11.5340 \\
2.59 & 24.2700 \\
3.59 & 38.4550 \\
4.59 & 52.8530 \\
5.59 & 66.5380 \\
6.59 & 78.7580 \\
7.59 & 88.8740 \\
8.59 & 96.3270 \\
9.59 & 100.6200 \\
10.59 & 101.2900 \\
11.59 & 97.9370 \\
12.59 & 90.1610 \\
13.18 & 83.3530 \\
\hline
\end{tabular}

\section{Conclusions}

The obtained results reveal that:

1) The temperature variation of the solar cell with the local day time is significant within the considered operating conditions.

2) The cooling conditions slightly affect the temperature of the cell.

3) The efficiency of the cell varies slowly with the local day time.

4) Computations reveal that the efficiency $\eta$ ranges between $21 \%$ - 28\% for the considered silicon cell. 
Table 4. The cell difference temperature as a function of local day time with the coefficient of heat transfer $\left(\mathrm{h}_{0}=10 \mathrm{~W} / \mathrm{m}^{2} \mathrm{~K}\right)$ and the thickness $\mathrm{d}=0.02 \mathrm{~m}$, taken as parameters.

\begin{tabular}{cc|}
\hline $\begin{array}{c}\text { Time } \\
\text { (hours) }\end{array}$ & $\begin{array}{c}\boldsymbol{\theta} \\
\mathbf{K}\end{array}$ \\
\hline 0 & 0 \\
1.59 & 11.3960 \\
2.59 & 23.8450 \\
3.59 & 37.6230 \\
4.59 & 51.5180 \\
5.59 & 64.6320 \\
6.59 & 76.2410 \\
7.59 & 85.7370 \\
8.59 & 92.5900 \\
9.59 & 96.3320 \\
10.59 & 96.5360 \\
11.59 & 92.8170 \\
12.59 & 84.8150 \\
13.18 & 77.9500 \\
\hline
\end{tabular}

5) As the solar cell temperature increases its efficiency decreases. Thus shading and cooling conditions may be useful to increase its efficiency.

\section{References}

[1] Joseph, J.W. and Paul, R. (1960) Effect of Temperature on Photovoltaic Solar Energy Conversion. Journal of Applied Physics, 31, 571-578. http://dx.doi.org/10.1063/1.1735630

[2] Blakers, A.W. and Green, M.A. (1986) 20\% Efficiency Silicon Solar Cells. Applied Physics Letters, 48, 20. http://dx.doi.org/10.1063/1.96799

[3] Olsen, L.C., Huber D.A., Dunham, G. and Addis, F. (1990) PC-ID Modeling of Depletion Layer Recombination in GaAs Solar Cells, IEEE, 1,415-419.

[4] Verlinden, P.J., Swanson, R.M., Sinton, R.A., Crane R.A., Tilford, C., Perkins, J. and Garrison, K. (1993) High-Efficiency, Point-Contact Silicon Solar Cells for Fresnel Lens concentrator Modules, IEEE, 58-64.

[5] Ray, K.P., Mullen, E.G. and Trumble, T.M. (1993) Results from the High Efficiency Solar Panel Experiment Flown on CREES. IEEE, Transactions on Nuclear Science, 40, 1505-1511.

[6] Zhao, J., Wang, A., Altematt, P.P., Wenham, S.R. and Green, M.A. (1994) 24\% Efficient Silicon Solar Cells. IEEE, 2, 1477-1480.

[7] Verlinden, P.J., Swanson, R.M. and Crane, R.A. (1994) 7000 High-Efficiency Cells for a Dream. Progress in Photo Voltaics: Research and Applications, 2, 143-152. http://dx.doi.org/10.1002/pip.4670020209

[8] Venkatasubramanian, R., Malta, D.P., Timmons, M.L., Posthill, J.B., Hutchby, J.A., Ahrekiet, A., Keyes, B. and Wangensteen, T. (1994) IEEE, 1692-1696.

[9] Wettling, W. (1995) High Efficiency Silicon Solar Cells; State of the Art and Trends. Solar Energy Materials and Solar Cells, 38, 487-500. http://dx.doi.org/10.1016/0927-0248(94)00240-1

[10] Bouazzi, A.S., Abaab, M. and Rezig, B. (1997) A New Model of Very High Efficiency Buried Emitter Silicon Solar Cell. Solar Energy Materials and Solar Cells, 46, 29-41. http://dx.doi.org/10.1016/S0927-0248(96)00091-8

[11] Yerokhov, V.Y., Melnyk, I.I. and Korovin, A.V. (1999) External Bias as the Factor of Efficiency Increase of Silicon MIS/IL Solar Cells. Solar Energy Materials and Solar Cells, 58, 225-236. http://dx.doi.org/10.1016/S0927-0248(98)00206-2

[12] Luque, V.D. and del Valle, C.A. (1999) On the Effects of Tilted Light in a Global Prediction of AlGaAs/GaAs Solar Cell Performance. Solar Energy Materials and Solar Cells, 57, 313-322. http://dx.doi.org/10.1016/S0927-0248(98)00188-3 
[13] Luque, A. and Marti, A. (1999) Limiting Efficiency of Coupled Thermal and Photovoltaic Converters. Solar Energy Materials and Solar Cells, 58, 147-165. http://dx.doi.org/10.1016/S0927-0248(98)00199-8

[14] Ferekides, C.S., Marinskiy, D., Viswanathan, V., Teltali, B., Palekis, V., Selvaraj, P. and Morel, D.L. (2000) High Efficiency CSS CdTe Solar Cells. Thin Solid Films, 361-362, 520-526. http://dx.doi.org/10.1016/S0040-6090(99)00824-X

[15] Laugier, A. and Roger, J.A. (1994) Les Photopiles Solaires. Part 2, Charpter 8, Technique and Documentation, Paris.

[16] Bouzek, K. and Kavan, L. (1999) Heat Losses in Gratzel Solar Cells. Solar Energy Materials and Solar Cells, 57, 359371. http://dx.doi.org/10.1016/S0927-0248(98)00189-5

[17] El-Adawi, M.K. and Al-Nuaim, I.A. (2007) The Temperature Functional Dependence of Voc for a Solar Cell in Relation to Its Efficiency-New Approach. Desalination, 209, 91-96. http://dx.doi.org/10.1016/j.desal.2007.04.014

[18] El-Adawi, M.K. and Al-Shameri, N.S. (2012) The Efficiency of a p-n Solar Diode as a Function of the Recombination Velocity within the Depletion Layer. Optics and Photonics Journal, 2, 326-331. http://dx.doi.org/10.4236/opj.2012.24040

[19] El-Adawi, M.K. and Al-Shameri, N.S. (2012) The Efficiency of the Solar Converter as a Function of the Doping Degrees and the Incident Solar Spectral Photon Flux. Canadian Journal on Scientific and Industrial Research, 3, 112-122.

[20] Markvart, T. (1994) Solar Electricity. Unesco Energy Series, Charpter 7, John Wiley \& Sons Ltd., UK.

[21] Stutenaumer, U., Negash, T. and Abdi, A. (1999) Performance of Small Scale Photovoltaic Systems and Their Potentials for Rural Electrification in Ethiopia. Renewable Energy, 18, 35-48. http://dx.doi.org/10.1016/S0960-1481(98)00784-8

[22] El-Adawi, M.K. and Al-Nuaim, I.A. (2010) The Temperature Variation of a Solar Cell in Relation to Its Performance. Journal of Environmental Science \& Engineering, 4, 56-59.

[23] Green, M.A. (1982) Solar Cells: Operating Principles Technology and System Applications. Prentice-Hall, Englewood Cliffs.

[24] Glunz, S.W. (2006) New Concepts for High-Efficiency Silicon Solar Cells. Solar Energy Materials \& Solar Cells, 90, 3276-3284. http://dx.doi.org/10.1016/j.solmat.2005.09.019

[25] El-Adawi, M.K., Abdelnaby, M.A. and Shalaby, S.A. (1995) Laser Heating of a Two-Layer System with Constant Surface Absorption: An Exact Solution. International Journal of Heat and Mass Transfer, 38, 947-952. http://dx.doi.org/10.1016/0017-9310(94)00162-O

[26] El-Adawi, M.K. and Al-Nuaim, I.A. (2001) Prediction of Diurnal Global Solar Irradiance on a Horizontal Surface General Approach. Proceedings of the 1st Saudi Science Conference, KFUPM, Saudi Arabia, 9-11 April 2001, 16, 6378.

[27] Duffiee, J.A. and Beckman, W.A. (1974) Solar Energy Thermal Processes. John Wiley\& Sons, New York.

[28] El-Bar, O. (1983) Energy Balance over Slant Surfaces. M.Sc. Thesis, Faculty of Meteorology and Environmental Science, King Abdul Aziz University, Jeddah.

[29] Spiegel, M.R. (1965) Laplace Transforms. Schaum’s Outline Series, McGraw-Hill, New York.

[30] Exkert, E.R.G. and Drake, R.M. (1972) Analysis of Heat and Mars Transfer. International Student Edition, Ch. 4, McGraw-Hill, Tokyo, 179.

[31] Bhattacharyya, A. and Streetman, B.G. (1981) Dynamics of Pulsed $\mathrm{CO}_{2}$ Laser Annealing of Silicon. Journal of Physics D: Applied Physics, 14, L67-L72. http://dx.doi.org/10.1088/0022-3727/14/5/002

[32] Tiwari, G.N. and Suneja, S. (1997) Solar Thermal Engineering Systems. Narosa Publishing House, London. 
Scientific Research Publishing (SCIRP) is one of the largest Open Access journal publishers. It is currently publishing more than 200 open access, online, peer-reviewed journals covering a wide range of academic disciplines. SCIRP serves the worldwide academic communities and contributes to the progress and application of science with its publication.

Other selected journals from SCIRP are listed as below. Submit your manuscript to us via either submit@scirp.org or Online Submission Portal.
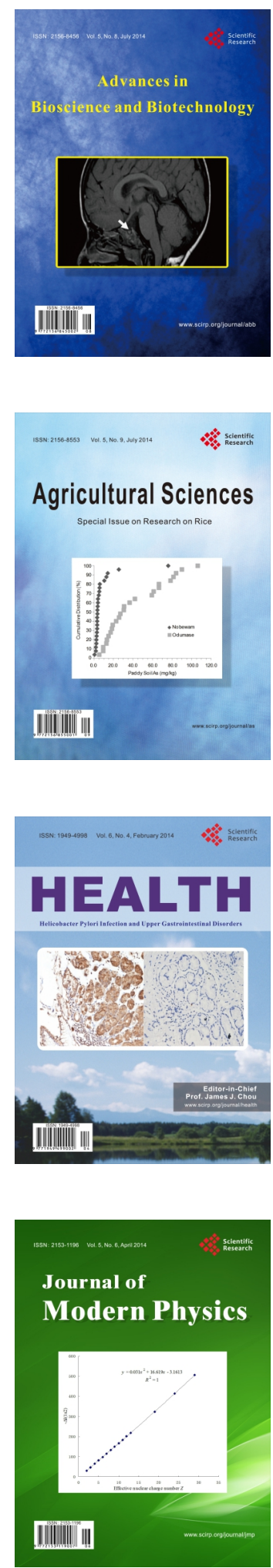
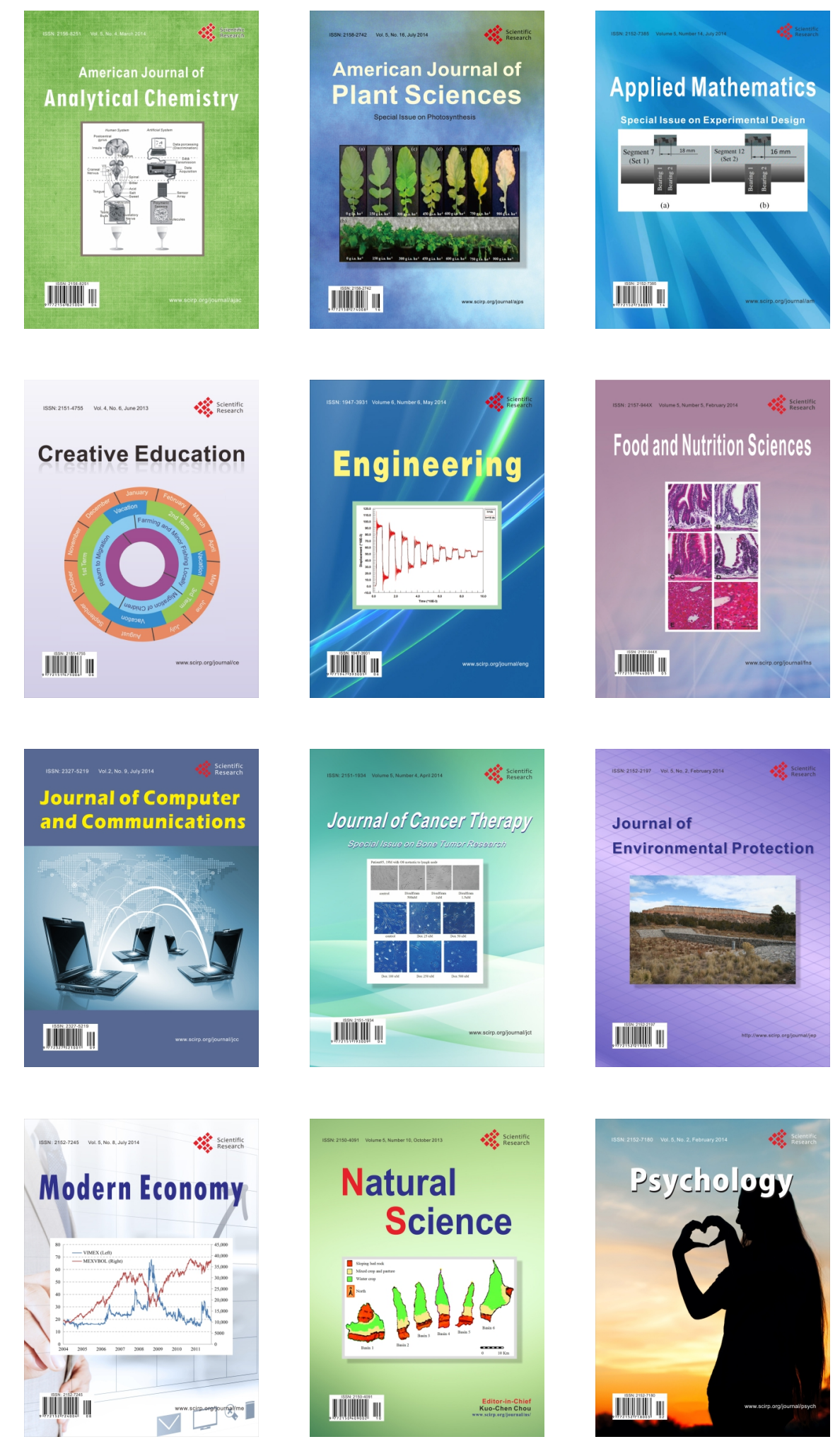